\title{
Travelling for Umrah: destination attributes, destination image, and post- travel intentions
}

Article

Accepted Version

Gannon, M. J., Baxter, I. W. F., Collinson, E., Curran, R., Farrington, T., Glasgow, S., Godsman, E. M., Gori, K., Jack, G. R. A., Lochrie, S., Maxwell-Stuart, R., MacLaren, A. C., Maclntosh, R., O'Gorman, K., Ottaway, L., Perez Vega, R., Taheri, B., Thompson, J. and Yalinay, O. (2017) Travelling for Umrah: destination attributes, destination image, and posttravel intentions. The Service Industries Journal, 37 (7-8). pp. 448-465. ISSN 1743-9507 doi:

https://doi.org/10.1080/02642069.2017.1333601 Available at https://centaur.reading.ac.uk/70393/

It is advisable to refer to the publisher's version if you intend to cite from the work. See Guidance on citing.

To link to this article DOI: http://dx.doi.org/10.1080/02642069.2017.1333601

Publisher: Routledge

All outputs in CentAUR are protected by Intellectual Property Rights law, including copyright law. Copyright and IPR is retained by the creators or other copyright holders. Terms and conditions for use of this material are defined in the End User Agreement. 


\section{www.reading.ac.uk/centaur}

\section{CentAUR}

Central Archive at the University of Reading

Reading's research outputs online 
Gannon, M., Baxter, I., Collinson, E., Curran, R., Farrington, T., Glasgow, S., Godsman, E., Gori, K., Jack, G., Lochrie, S., Maxwell-Stuart, R., MacLaren, A., MacIntosh, R., O'Gorman, K., Ottaway, L., Perez-Vega, R., Taheri, B., Thompson, J., \& Yalinay, O. (Forthcoming). Travelling for Umrah: Destination attributes, destination image, and post-travel intentions, The Service Industry Journal.

\title{
Travelling for Umrah: Destination attributes, destination image, and post-travel intentions
}

\begin{abstract}
This paper examines the links between cosmopolitanism, self-identity, and a desire for social interaction perceived destination image and behavioural intentions. A model tested using a sample of 538 Iranian visitors to Mecca for the purpose of Umrah. The result from the structural model suggests that destination attributes influence perceived destination image. Further, such tourists are likely to revisit or recommend Islamic destinations if their experience matches their perceived image of the destination. This implies that, while the religious characteristics of the destination remain important, destination managers cannot disregard the tangential, non-religious attributes of a destination which are crucial in order to satisfy more conventional tourist desires. As such, this study suggests that those managing religious travel destinations should endeavour to foster a welcoming image, where experience, interaction and tolerance are at the forefront of the destination's offering.
\end{abstract}

Keywords: Perceived Destination Image; Cosmopolitanism; Behavioural Intention; SelfIdentity; Social Interaction 


\section{Introduction}

Located in the Hejaz region of Saudi Arabia, the holy city of Mecca hosts over 8 million tourists annually, contributing \$12bn to the Saudi economy, and encouraging significant recent improvements in both service provision and innovation (La Finanza Islamica, 2017). Typically, their purpose for travel centres on either the compulsory undertaking of Hajj, one of the five pillars of Islam, or the voluntary lesser religious pilgrimage, Umrah (El-Gohary \& Eid, 2014; Zamani-Farahani \& Henderson, 2010; Zamani-Farahani \& Eid, 2016; Jafari \& Scott, 2014). Hajj sees Mecca's population treble (Eid, 2015), and represents a journey that physically and financially capable Muslims are obliged to undertake at least once in their lifetime, during the final month of the Islamic calendar, in order to demonstrate solidarity with their faith. While still popular and of religious importance to Muslims, Umrah can be undertaken at any point throughout the year and is not considered compulsory (Jafari \& Scott, 2014).

Given its religious importance, those visiting Mecca undoubtedly travel with a preconceived notion of what to expect from Islam's holiest city, and religious travel has proved an increasingly prevalent and interesting area for research, where particular attention is given to the motivations, expectations, needs and experiences of those undertaking such travel (El-Gohary \& Eid, 2014; Eid \& El-Gohary, 2015; Jutla, 2002; Henderson, 2011; Kim, Im, \& King, 2015; Oktadiana, Pearce, \& Chon, 2016). With this in mind, Prayag and Hosany (2014) classify travel motivations into two categories. The first concerns self-serving factors, such as a need for relaxation or a desire to experience something different, which 'push' an individual towards more general travel. In contrast, they suggest that the perceived notion of destination-led attributes, such as natural resources, cultural attractions, facilities, and the general ambiance, serve to 'pull' tourists towards specific destinations (Prayag \& Hosany, 2014). The focus of this paper is therefore concerned with tourists who have undertaken voluntary travel to Mecca on the lesser pilgrimage of Umrah, as opposed to the obligatory Hajj (Jafari \& Scott, 2014). Here, the image of the destination may play a more important role with regards to tourists' behavioural intentions to revisit the city or recommend such travel to others, as they are pulled towards travel to Mecca on a non-compulsory basis, as opposed to being compelled to for purely religious or spiritual reasons. 
This 'destination image' concerns tourists' pre-travel perceptions of a destination's attributes along with their overall impression of the destination as a whole, and is one of the most important concepts in tourism marketing management studies, particularly with regards to destination positioning and the destination selection process (Stylos, Vassiliadis, Bellou, \& Andronikidis, 2016; Horng, Liu, Chiu, \& Tsai, 2012; Lin, Lin, \& Ryan, 2014; Lee \& Back, 2007; Martín-Santana, Beerli-Palacio, \& Nazzareno, 2017; Martin, Gil-Pechuan, \& Soriano, 2011; Wang, 2012). It is comprised of three core elements: tourists' perceived understanding of the characteristics and attributes that embody a destination; the emotional response generated when considering travel to a destination; and tourists' overall impression of the destination (Martin-Santana, BeerliPalacio \& Nazzereno, 2017). The importance of the first of these core elements, labelled as perceived destination image, is well-established within travel and tourism literature (Prayag \& Hosany, 2014).

Further, previous studies indicate that destination-led attributes, such as the prevalence of high quality attractions (Martín-Santana et al., 2017), the openness and tolerance of the destination (Hughes et al., 2010), and the likelihood of interacting with likeminded individuals (Park \& Yoon, 2009) influence perceived destination image. Indeed, cosmopolitan travel is established as relating to the open-mindedness, cultural diversity, and tolerance of a destination, with many destinations partially defined by these characteristics (Cannon \& Yaprak, 2002; Hughes, Monterrubio, \& Miller, 2010). Similarly, travel can help to strengthen and maintain self-identity (Eid, 2015), or help to engender a new sense of self-identity as it can provide tourists with the opportunity to fulfil ambitions, make positive lifestyle changes, or reinforce significant elements of their character (Bond \& Falk, 2013). Self-identity is strongly linked with religious travel, yet few studies consider this beyond the structured notion of pilgrimage (Jafari \& Scott, 2014). Further, this study considers tourists' desire for social interaction, where social relationships and a desire to feel a sense of belonging to a wider group are considered important in stimulating travel (Prayag \& Hosany, 2014). Travel is inherently social, and the opportunity for positive social interactions is established as being important in shaping perceived destination image (Mahallati, 2011; Granger, Lu, Conduit, Veale, \& Habel, 2014; Wu, 2011). Each of the above concepts can also help destination managers and marketers to understand tourists' post-travel behavioural intentions with regards to 
whether they are likely to revisit the destination, or to recommend it to others (Horng et al., 2012). Nonetheless, there remains little investigation into the importance of each of these concepts in shaping perceived destination image and tourists' subsequent behavioural intentions in Islamic travel contexts.

To this end, a three-stage conceptual process has been developed from services marketing and tourism literature to advance the 'bivariate links between service encounter and behavioural intentions' (Zabkar, Brencic \& Dmitrovic, 2010; Prayag \& Hosany, 2014; Brady et al., 2005; Phillips, Wolfe, Hodur \& Leistritz, 2013), which emphasises the relationship between the attributes of a destination, perceived destination image and behavioural intentions. Zabkar et al. (2010) argue that destination attributes impact on perceived destination image (i.e., quality of a destination's offering: a bundle of components including customised activities, accessibility, luxury services and culture). In this instance, perceived destination image also influences post-travel evaluations and future behaviour intentions, including recommendations to others and the intention to revisit a destination.

Thus, we echo the call for further investigation into the relationships between these antecedent factors and their influence on perceived destination image and behavioural intentions in religious travel settings (e.g., Chen, Chen \& Okumus, 2013; ElGohary \& Eid, 2014; Prayang \& Hosnay, 2014). More precisely, the study aims to enhance current knowledge of the impact of antecedents of destination image (cosmopolitanism, desire for social interaction, and self-identity) and their influence on both perceived destination image and behavioural intentions within the Islamic tourism context. We build and test a conceptual model that explores whether the aforementioned antecedent factors influence tourists' intention to revisit or recommend travel to Mecca for Umrah. Finally, this paper advances the application of Partial Least Squares in tourism research by using the technique to test the conceptual framework. Finally, the paper discusses the theoretical and managerial implications emerging from the findings, provides suggestions for further avenues of investigation, and acknowledges the limitations of the study.

\section{Literature review}


The role of perceived destination image in shaping travel decisions is complex (Oktadiana et al., 2016; Martin-Santana et al., 2017), and refers to the cognitive way in which tourists view destinations prior to travel (Prayag \& Hosany, 2014). It guides behaviour before, during, and after travel (Chen, Chen, \& Okumus, 2013) and can be influenced by existing knowledge of the destination or others' suggestions (Dolnicar \& Grün, 2012; El-Gohary \& Eid, 2014; Eid \& El-Gohary, 2015). However, it is affected by the role of tourists' personal motivations, prior experiences, traits and characteristics in shaping their perception of a destination (Martin-Santana et al., 2017; El-Gohary \& Eid, 2014). Sirgy and $\mathrm{Su}(2000)$ commented that, similar to how people purchase branded products based on their view of those who consume them, they have a perceived image of destinations based on those who typically travel there; the more aligned the destination visitor image and the tourist's self-concept, the greater likelihood the tourist has a favourable attitude towards that destination.

This self-congruence suggests a relationship between perceived self-identity and perceived destination image. Tourists consume destinations similarly to branded products, using each to express their own identity and differentiating themselves from others (Berger \& Heath, 2007). As such, antecedent factors, such as socio-demographic identity and culture combine to shape perceived destination image for some tourists (Kim \& Prideaux, 2005). For example, British tourists seek destinations that they consider to be thrilling and exciting; whereas Germans are titillated by destinations they consider relaxing and tranquil (Kim \& Prideaux, 2005). In their exploration of Arab travel to Western countries, Prayag and Hosany (2014) advocate a range of factors that contribute to perceived destination image, and suggest that tourists build their image of destinations based on their perception of its overall offering (Zabkar et al., 2010). This includes: its accessibility; the range and quality of activities and amenities; the prevalence of luxury services; its reputation; shopping; dining; culture; and weather (El-Gohary \& Eid, 2014; Prayag \& Hosany, 2014). In the Islamic context, image is more widely built upon the perception of a destination's ability to adhere to food service requirements through the availability of Halal produce (Battour, Ismail, \& Battour, 2011) and shaped by: the availability of places of worship (Eid, 2015); attitudes to alcohol consumption; gambling (Henderson 2003); sexual permissiveness (Zamani-Farahani \& Henderson, 2010); and dress-code (Zamani-Farahani \& \& Henderson, 2010). 
Nonetheless, perceived destination image in the context of Islamic culture is under-researched (Chen et al., 2013) and existing literature focuses on traditional multicultural tourist destinations in Islamic countries (Zamani-Farahani \& Henderson, 2010; Battour et al., 2011). However, Islamic tourist destinations vary widely in purpose. At sites of religious importance, such as Mecca, Islamic belief and practice converge and deliver a strong religious image, bolstered by its underlying importance to the Islamic faith (Eid, 2015). This is enhanced when considering the Islamic image of Mecca, where the religious importance of the site significantly outweighs its many physical attributes. As such, Islamic tourists may only partially hold a perceived image routed in climate or cuisine. Indeed, such tourists seek something "less tangible than the trip itself and more rewarding than just being there" (Mannell \& Iso-Ahola, 1987, p.348). For Muslims undertaking Umrah, Prayag and Hosany (2014) assertion that tourists are likely to question whether local cuisine complies with their religious beliefs is probably unnecessary. When considering culture and weather, those undertaking religious travel tend to be aware of the cultural and religious importance of the destination, and the journey itself, and are unlikely to be influenced in their decision to travel by factors such as weather or climate (Eid, 2015).

Nonetheless, religious tourists expect a standard of quality and service when visiting sites of religious importance and perceive a destination's image with this in mind (El-Gohary \& Eid, 2014; Henderson, 2011). There is burgeoning interest in the luxurious side of religious travel, with emphasis on Muslim tourists and their increasing expectation regarding the quality of accommodation, transport, and non-spiritual activities in areas immediately surrounding Mecca's Grand Mosque and the ancient city of Medina (Henderson, 2011). For Islamic destinations, it is not sufficient to rest on the laurels of piety. Their perceived image must encompass more than its overriding religious importance (Prayag \& Hosnay, 2014), whilst also surpassing the outmoded and entrenched western perception of the purpose of pilgrimage.

\section{Effect of cosmopolitanism on perceived destination image}


The term cosmopolitanism was appropriated into sociological vernacular by Merton (1957) and is now established within tourism research (Cannon \& Yaprak, 2002). Conventionally, cosmopolitanism encompasses the predisposition of an individual to consider themselves beyond the peripheries of their local community (Merton, 1957). However, contemporary understanding of the concept extends this and can be attributed to destinations as well as individuals (Hui \& Wan, 2003; Smith, 2006). This instead centres on the virtues of open-mindedness with regards to foreign cultures, an appreciation of diversity, and a positive disposition towards brands and products of international origin (Weaver, 2017). It is generally the preserve of the relatively affluent, well-educated, and well-travelled (Maitland, 2008). A cosmopolitan orientation leads tourists to consume destinations, experiences and products from cultures beyond their own and to gain a better understanding of different cultures (Cannon \& Yaprak, 2002), neutralising any predilections born from local influences.

A profound pre-existing knowledge of other cultures is not essential; instead, it is their readiness to become engaged with other cultures, even the unknown, which distinguishes cosmopolitans (Hannerz, 1990). Similarly, the perception of a destination as 'cosmopolitan' encourages tourism (Smith, 2006), where a 'cosmopolitan' destination image is used to form its 'personality' ( $\mathrm{Qu} \& \mathrm{Qu}, 2015)$. There is an expectation that destinations should have high standards of tolerance and safety (Hughes et al., 2010), varied shopping and food amenities (Hui \& Wan, 2003), and numerous cultural attractions (Maitland, 2008).

Traditionally, Islamic destinations have struggled with engendering a 'cosmopolitan' image. This is due to their inherent conservatism (Aziz, 1995; Burton, 1995), a desire to shield citizens from 'harmful' external cultures, stimuli or influences (Henderson, 2003), and a need to adhere to belief-related norms surrounding alcohol consumption, and attitudes towards sex and gambling (Aziz, 1995; Chen et al., 2013). These are incongruent with the open-mindedness, cultural diversity, and tolerance of other cultures espoused by the understanding of cosmopolitanism dominated by secular ideals (Cannon et al., 2002). However, the perceived destination image of some Islamic destinations increasingly conforms to aspects and elements of cosmopolitanism, such as offering tourists the safety to enjoy high-quality cultural attractions, local food, and shopping, while maintaining an established religious image (Henderson, 2011; Prayag \& 
Hosany, 2014). This perceived destination image has developed to the extent where traditionally Islamic destinations, such as the UAE (Choi, Law, \& Heo, 2016), Turkey (Tosun et al., 2007), and Malaysia (Henderson, 2003; Battour et al., 2011; Mura, 2015) are perceived as relative hotbeds of cosmopolitanism. Based on these arguments, we postulate that:

H1: Cosmopolitanism is positively related to perceived destination image.

\section{Effect of self-identity on perceived destination image}

The role and importance of identity is established within travel and tourism research (Jang, Lee, Park, \& Stokwsli, 2000; Bond et al., 2013; Nelson, 2015). Travel can be used to construct, maintain, or strengthen self-identity across a range of aspects, from core values such as gender, nationality, and religion through to softer, less-defined criteria such as conceptualisations of one's own success (Noy, 2004; Bond et al., 2013; Nelson, 2015). Although core-identity attributes such as religious denomination are unlikely to influence all travel decisions (Bond et al., 2013), it can affect those travelling to Islamic destinations. This is particularly evident with forms of religious travel, which are used to strengthen faith, show devotion, and are central tenets of many major religions (Jutla, 2002; Jafari \& Scott, 2014). Thus, some religious tourists seek destinations whose image encourages them to believe that they can strengthen the religious elements of their selfidentity in a positive manner. Given this, the perceived image of a destination may be positively influenced by whether it conforms to the requirements of their religious selfidentity (Eid, 2015). As such, we hypothesise:

H2: Self-identity is positively related to perceived destination image.

\section{Effect of desire for social interactions on perceived destination image}

A desire for social interaction often acts as an important precursor to travel (Lee et al., 2004; Park et al., 2009; Rosenbaum, 2015; Wu, 2011). For example, Chang (2006) found that the perceived likelihood of social interaction served to motivate those travelling to cultural festivals in Taiwan, echoing Formica and Uysal (1996) who suggested that a 
desire for social interaction affects an individual's attachment, expectation, or experience of an event and influences their perceived image of a destination.

A desire for social interaction has a positive relationship with religious and spiritual travel (El-Gohary \& Eid, 2014; Jutla, 2002; Jafari \& Scott, 2014), and this is particularly prominent in the case of Islamic pilgrimage. Here, there is a desire for interaction and a perceived need to belong, driven by the sanctity of fostering a sense of "brotherhood" and togetherness (Jafari \& \& Scott, 2014). The capacity of a destination to provide a platform for this form of social acceptance and a sense of kinship through religious and ideological harmony is important in building its overall perceived image (Mahallati, 2011). In spiritual communities, where pilgrimage is deemed to hold a certain value, travel decisions are often made based on the likelihood of feeling comfortable and accepted in the company of those who share beliefs, customs, and norms (Granger, Lu, Consuit, Veal, \& Habel, 2014; Mahallati, 2011). Ultimately, if a travel destination is perceived as providing this opportunity, a desire for social interaction is likely to have a positive impact on the overall image of destinations with spiritual or religious components (Granger et al., 2014; Jafari \& Scott, 2014). Therefore, we postulate that:

H3: A desire for social interaction is positively related to perceived destination image.

\section{Effect of antecedents and perceived destination image on behavioural intention}

Previous studies have explored how various concepts, such as destination image, contribute to behavioural intentions (Chen \& Tsai, 2007; El-Gohary \& Eid, 2014; Stylos et al., 2016; Zabkar et al., 2010), with Zhang et al. (2014) suggesting that self-image and cultural evaluation influence behavioural intentions. Within tourism, the concept of behavioural intention has primarily considered a tourist's projected future behaviour and their likelihood to act in a particular way pre-, during and post-travel (Yuan, Morrison, Cai, \& Linton, 2008; Li \& Cai, 2012; Stylos et al., 2016). When considering positive posttravel behavioural intentions, the importance of two particular elements is established; whether the tourist expects to revisit a destination (Moutinho, Albayrak, \& Caber, 2012) and whether they intend to recommend a destination to others (Tsai, 2016).

Both revisit intentions and intention to recommend emerge post-travel, and are induced by general satisfaction with the destination (Prayag \& Hosany, 2014), perception 
of the quality of destination amenities and attractions (Žabkar et al., 2010; Martin-Santana et al., 2017) and 'good value' (Yuan et al., 2008; Žabkar et al., 2010). The perceived destination image, with regards to the distinctiveness of a destination, can also contribute to revisit intentions (Chen et al., 2007). The functional reality of the overall travel experience influences whether they subsequently choose to endorse a destination to others (Tsai, 2016), and destinations where attractions are perceived as 'high-quality' increase tourists' intention to revisit (Moutinho et al., 2012). Given the importance of the quality and value of the travel experience, the perceived image of a destination is important in engendering positive behavioural intentions (Ekinci \& Hosany, 2006; Prayag \& Hosany, 2014). If pre-travel perceptions of a destination are realised during-travel, positive posttravel behavioural intentions are likely (Lee et al., 2005). Tourists seeking to affirm their self-identity while surrounded by likeminded individuals are unlikely to revisit or recommend a destination if their expectations are not met. Therefore, it is important for destinations to carefully craft and manage perceived image (Ekinci \& Hosany, 2006).

Here, Islamic destinations may hold an advantage, as they typically have an established perceived image with regards to the quality and availability of facilities and adherence to Islamic conventions (Battour et al., 2011; El-Gohary \& Eid, 2014; Prayag \& Hosany 2014), which is likely to increase gratification, bolster self-identity, and result in positive behavioural intentions. While some forms of pilgrimage are considered 'once in a lifetime', destinations facilitating this require repeat visits in order to generate enough interest and income to improve their overall service offering. Similarly, for those undertaking religious travel to Islamic destinations, the likelihood of social interaction with likeminded individuals is established (Jafari \& Scott, 2014; Granger et al., 2014) and, if realised, may engender recommendation or revisit intentions. As travel increasingly requires destinations to provide a more refined and cosmopolitan offering (El-Gohary \& Eid, 2014; Prayag \& Hosany, 2014), delivering aspects of this, such as the provision of distinct and diverse experiences (Tosun et al., 2007), may increase tourists' enjoyment, and result in a higher degree of revisit or recommendation intentions. Despite this, the reality of behavioural intentions is not absolute, particularly with regards to revisit intentions where more practical factors, such as time commitments and the tourist's financial capabilities can supersede their desire to return to the destination (Nadeau, Heslop, O'Reilly, \& Luk, 2008). Nonetheless, we hypothesise: 
H4: Perceived destination image is positively related to behavioural intention.

H5: Cosmopolitanism is positively related to behavioural intention.

H6: Self-identity is positively related to behavioural intention.

H7: Desire for social interaction is positively related to behavioural intention.

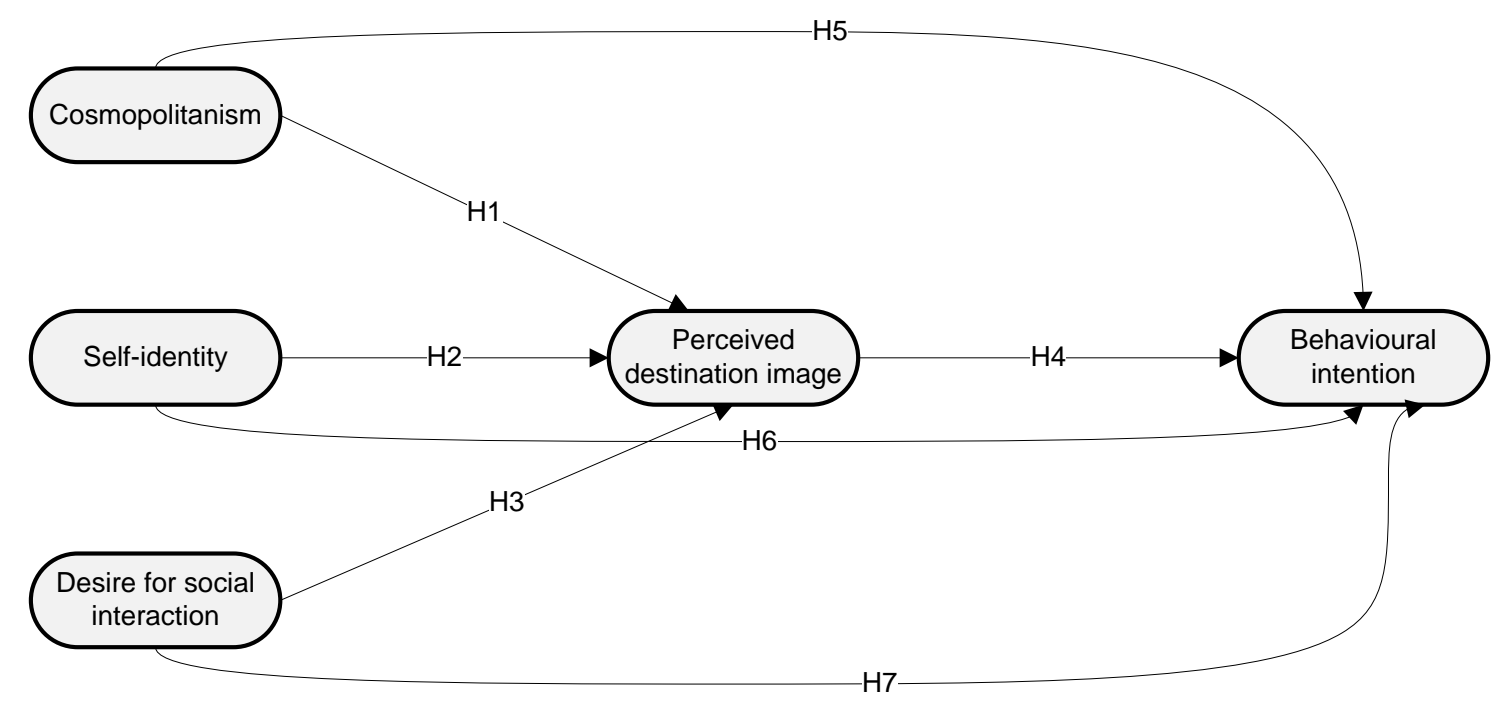

Figure 1. Conceptual model.

\section{Methodology}

\section{Sample and measures}

This study used a survey method, using a questionnaire to test the developed hypotheses.

The questionnaires were distributed during face-to-face interactions between travel agents and Muslim travellers inside a popular agency chain in one of the most populated cities in Iran over a three month period in 2014. At the request of the agency, all identifiable information has been anonymized. The research team provided exact instructions to the travel agents regarding the distribution of questionnaires. Using convenience sampling, data was obtained from Iranian Muslim travellers (who visited Mecca for Umrah purpose and subsequently returned back to Iran), under the researchers' supervision. Umrah was selected, as it is a lesser pilgrimage experience and offers a more voluntary religious travel experience when compared to the obligatory Hajj (El-Gohary \& Eid, 2014; Haq \& Jackson, 2009; Jafari \& Scott, 2014). The questionnaire used backtranslation to avoid language errors, and was checked by local academic, native Farsi speakers. A pilot study was employed to check the wording of the questionnaire before data collection commenced. Overall, 650 questionnaires were distributed, with 538 
useable questionnaires received, yielding a satisfactory response rate (Fowler, 2002). Demographically, $52.6 \%$ of the sample was female and the rest were male. $10.5 \%$ of respondents were between 18 and 35 years old, $14.5 \%$ were between 36 and 45 years old, $29 \%$ were between 46 and 55 years, and finally $46.1 \%$ of the sample was 56 years old or older. To test non-response bias, we compared the early and late responses to the questionnaire based on the differences in characteristics. The results indicated no significant differences, thus non-response bias was not a threat for this study (Armstrong \& Overton, 1977).

To ensure content validity, the items of the measures were adapted from previous studies: Self-identity (4-items) (Jang et al., 2000), Desire for Social Interaction (5-items) (Granger et al., 2014), Cosmopolitanism (4-items) (Cleveland et al., 2013), Perceived Destination Image (19-items) (Prayag \& Hosnay, 2014), and Behavioural Intention (4items) (Nadeau et al., 2008; Zabkar et al., 2010). The participants were asked to indicate their level of agreement or disagreement with the statements, using a 7-point Likert-type scale from 1 = strongly disagree to 7 = strongly agree (Appendix 1 ).

\section{Common method variance}

As data was collected from a single-source, we tested for the presence of common method variance (Podsakoff, MacKenzie, Lee, \& Podsakoff, 2003). The anonymity of participants was guaranteed and dependent and independent variables were placed in different parts of the questionnaire. Harman's one factor test was used to test common method variance. The findings of the unrotated exploratory factor analysis detected six factors (F1: 14.070; F2: 4.133, F3: 2.587, F4: 1.921, F6: 1.557, and F6: 1.011) with the eigenvalue greater than 1, explaining only $78.998 \%$ total variance with the first factor showing $43.970 \%$ (which is $<50 \%$ recommended value); common method variance was not violated.

\section{Analytical approach}

Partial least squares structural equation modelling (PLS-SEM) has gained importance in services and tourism research (Walsh, Yang, Dose, \& Hille, 2015; Weitlaner \& Kohlbacher, 2015; Wells, Taheri, Gregory-Smith, \& Manika, 2016). PLS-SEM was used to test the conceptual framework as it is less sensitive to distributional abnormality (Hair, 
Hult, Ringle, \& Sarstedt, 2014). Skewness and kurtosis values for some variables were above the suggested threshold of -3 and +3 (Wells et al., 2016) (Appendix 1); thus, the assumption of normality was violated. Secondly, this is preferable when research examines new relationships and relatively new concepts in a structural model (Chin, 2010; Hair et al., 2014; Wells et al., 2016). Both the measurement and structural model were assessed within SmartPLS 3.0 software (Ringle, Wende, \& Becker, 2014). The nonparametric bootstrapping technique was used to calculate with 538 cases (5000 subsamples).

\section{Results}

\section{Measurement model}

Cronbach's Alpha $(\alpha)$, Composite reliability (CR), factor loadings, average variance extracted (AVE) and correlation matrix were employed to test reliability, convergent and discernment validity (Hair et al., 2014). Table 1 shows Cronbach's $\alpha$ and CR for measurement scales exceeded the suggested threshold of 0.70 (Hair et al., 2014). All factor loadings were greater than 0.60 and thus significant. Hence, the measurement scales used are reliable. Convergent and discernment validity were measured in various ways. First, the AVE values reached the cut-off of 0.5 for all measurement scales. Second, Fornell and Larcker's (1981) criterion was employed, which all scales met. Third, Henseler et al.'s (2015) recommendation was followed by using the heterotrait-monotrait ratio of correlation (HTMT) approach. All HTMT values in the model were below the cut-off of 0.85 (ranging from 0.509-0.611). Therefore, the measurement scales have suitable convergent and discriminate validity.

Table 1. Reliability and validity results

\begin{tabular}{|c|c|c|c|c|c|c|c|c|c|}
\hline $\begin{array}{l}\text { Measurement } \\
\text { scales }\end{array}$ & $\begin{array}{l}\text { Range of } \\
\text { loadings } \\
*\end{array}$ & $\begin{array}{l}\text { Cronbach' } \\
\text { s } \alpha\end{array}$ & $\mathrm{CR}$ & $\begin{array}{l}\mathrm{AV} \\
\mathrm{E}\end{array}$ & (1) & (2) & (3) & (4) & (5) \\
\hline (1)Cosmopolitanis & $0.784-$ & 0.865 & 0.90 & 0.71 & 0.84 & & & & \\
\hline $\mathrm{m}$ & 0.921 & & 8 & 3 & 4 & & & & \\
\hline (2)Desire for social & $0.700-$ & 0.850 & 0.89 & 0.62 & 0.59 & 0.79 & & & \\
\hline interaction & 0.858 & & 3 & 7 & 7 & 2 & & & \\
\hline (3)Behavioural & $0.747-$ & 0.855 & 0.89 & 0.63 & 0.59 & 0.58 & 0.79 & & \\
\hline intention & 0.849 & & 5 & 1 & 3 & 5 & 4 & & \\
\hline (4)Perceived & $0.611-$ & 0.932 & 0.94 & 0.58 & 0.61 & 0.62 & 0.64 & 0.76 & \\
\hline destination image & 0.837 & & 2 & 5 & 5 & 9 & 0 & 4 & \\
\hline
\end{tabular}


Notes: *t-values for the item loadings to two-tailed test: $t>3.29$ at $p<.001$. The diagonal in boldface represents the square root of AVE.

\section{Structural model and key findings}

Five main approaches were used to assess the structural model (Henseler, Ringle, \& Sinkovics, 2009). First, cross validation communality and redundancy indices were used to verify the quality of the PLS-SEM model and its predictive relevance (Wells et al., 2016). Blindfolding technique in PLS-SEM was used to assess this. Five and ten omission distance was used, which did not integer with regards to the sample size of 538 (Table 2). Second, $R^{2}$ values were above the cut-off point $(0.10)$ in the PLS-SEM. Third, goodness of fit (GoF) was 0.635 , which shows a large effect size. Fourth, $f^{2}$ (Table 3) values of direct paths in the inner model were significant and above the suggested threshold of 0.02 (small), 0.15 (medium) and 0.35 (large) (Cohen, 1988). Finally, Standardized Root Mean Square Residual (SRMR), as another GoF indicator, was calculated. The SRMR value for in this model was 0.061 , which is below the suggested value of 0.08 (Henseler et al., 2014).

Table 2. Blindfolding results

\begin{tabular}{|c|c|c|c|c|c|}
\hline \multirow[b]{2}{*}{ Measurement scale } & \multirow[b]{2}{*}{$\mathrm{R}^{2}$} & \multicolumn{2}{|c|}{ Omission distance $=5$} & \multicolumn{2}{|c|}{ Omission distance $=10$} \\
\hline & & $\begin{array}{l}\text { Communality } \\
\mathrm{Q}^{2}\end{array}$ & $\begin{array}{l}\text { Redundancy } \\
\mathrm{Q}^{2}\end{array}$ & $\begin{array}{l}\text { Communality } \\
\mathrm{Q}^{2}\end{array}$ & $\begin{array}{l}\text { Redundancy } \\
\mathrm{Q}^{2}\end{array}$ \\
\hline Cosmopolitanism & $\mathrm{n} / \mathrm{a}$ & 0.509 & $\mathrm{n} / \mathrm{a}$ & 0.517 & $\mathrm{n} / \mathrm{a}$ \\
\hline $\begin{array}{l}\text { Desire for social } \\
\text { interaction }\end{array}$ & $\mathrm{n} / \mathrm{a}$ & 0.112 & $\mathrm{n} / \mathrm{a}$ & 0.111 & $\mathrm{n} / \mathrm{a}$ \\
\hline Behavioural Intention & $\mathrm{n} / \mathrm{a}$ & 0.422 & $\mathrm{n} / \mathrm{a}$ & 0.431 & $\mathrm{n} / \mathrm{a}$ \\
\hline $\begin{array}{l}\text { Perceived destination } \\
\text { image }\end{array}$ & 0.809 & 0.448 & 0.370 & 0.446 & 0.370 \\
\hline Self-identity & 0.504 & 0.432 & 0.305 & 0.447 & 0.303 \\
\hline
\end{tabular}

Nonparametric bootstrapping procedure was used to assess the path coefficients between the direct relationships. Table 3 shows the following positive relationships: cosmopolitanism and perceived image ( $\mathrm{H} 1: \beta=0.324, p<0.001)$; self-identity and perceived destination image (H2: $\beta=0.178, p<0.001)$; desire for social interaction and perceived destination image (H3: $\beta=0.509, p<0.001)$; perceived destination image and behavioural intention ( $\mathrm{H} 4: \beta=0.149, p<0.01$ ); cosmopolitanism and behavioural intention (H5: $\beta=0.505, p<0.001)$, and desire for social interaction and behavioural intention (H7: $\beta=0.125, p<0.01$ ). Thus, $\mathrm{H} 1, \mathrm{H} 2, \mathrm{H} 3, \mathrm{H} 4, \mathrm{H} 5$ and $\mathrm{H} 7$ were supported. However, the impact of self-identity on behavioural intention was not significant (H6: $\beta=0.023$, non- 
significant); thus, H6 was rejected. Gender and age were the control variables and only gender had significant impact.

Table 3. Assessments of direct paths

\begin{tabular}{llll}
\hline Path & $\begin{array}{l}\text { Path } \\
\text { coefficient }\end{array}$ & $\begin{array}{l}t \text { - } \\
\text { values }\end{array}$ & $f^{2}$ \\
\hline Cosmopolitanism $\rightarrow$ Perceived destination image & 0.324 & 6.306 & 0.154 \\
Self-identity $\rightarrow$ Perceived destination image & 0.178 & 5.299 & 0.050 \\
Desire for social interaction $\rightarrow$ Perceived destination & 0.509 & 17.971 & 0.340 \\
image & & & \\
Perceived destination image $\rightarrow$ Behavioural intention & 0.149 & 2.897 & 0.070 \\
Cosmopolitanism $\rightarrow$ Behavioural intention & 0.505 & 8.135 & 0.418 \\
Self-identity $\rightarrow$ Behavioural intention & 0.023 & 1.280 & 0.050 \\
Desire for social interaction $\rightarrow$ Behavioural intention & 0.125 & 2.507 & 0.060 \\
Age $\rightarrow$ Cosmopolitanism & 0.045 & 1.036 & \\
Age $\rightarrow$ Self-identity & 0.037 & 0.761 & \\
Age $\rightarrow$ Desire for social interaction & 0.059 & 1.263 & \\
Age $\rightarrow$ Perceived destination image & 0.009 & 0.457 & \\
Age $\rightarrow$ Behavioural intention & 0.013 & 0.443 & \\
Gender $\rightarrow$ Cosmopolitanism & 0.037 & 0.913 & \\
Gender $\rightarrow$ Self-identity & 0.031 & 0.547 & \\
Gender $\rightarrow$ Desire of social interaction & 0.075 & 1.663 & \\
Gender $\rightarrow$ Perceived destination image & 0.054 & 3.632 & \\
Gender $\rightarrow$ Behavioural intention & 0.117 & 3.084 & \\
\hline Notes: Significant at $* t>1.96$ at $p<.05 ; * * t>2.57$ at $p<.01 ; * * * t>3.29$ at $p<.001$ &
\end{tabular}

\section{Post-hoc analysis of indirect effects}

The PLS-SEM analysis suggested the potential existence of mediating relationships between some measurement scales. Williams and MacKinnon's (2008) two-step bootstrapping procedure was followed. 95\% confidence interval $(\mathrm{CI})$ of the parameter estimates by resampling 5,000 times was used. As shown in Table 4, the results indicate the indirect influence of cosmopolitanism on behavioural intention through perceived destination image $(95 \% \mathrm{CI}=[0.067,0.118])$. Since the direct influence was significant, there is partial mediation. The findings show self-identity has an indirect impact on behavioural intention through perceived destination image $(95 \% \mathrm{CI}=[0.102,0.138])$. Since the direct effect was not significant, the findings showed that perceived destination image fully mediates the influence of self-identity on behavioural intention. Finally, the results revealed the indirect influence of desire for social interaction on behavioural intention through perceived destination image $(95 \% \mathrm{CI}=[0.058,0.098])$. Since the direct 
effect was significant, perceived destination image partially mediates the influence of desire for social interaction on behavioural intention.

Table 4: Assessments of indirect paths

\begin{tabular}{|c|c|c|c|c|}
\hline Path & $\begin{array}{l}\text { Indirect } \\
\text { effect }\end{array}$ & $\begin{array}{l}t- \\
\text { values }\end{array}$ & $\begin{array}{l}\text { Low } \\
\text { CI }\end{array}$ & $\begin{array}{l}\text { High } \\
\text { CI }\end{array}$ \\
\hline $\begin{array}{l}\text { Cosmopolitanism } \rightarrow \text { Perceived destination } \\
\text { image } \rightarrow \text { Behavioural intention }\end{array}$ & 0.084 & 2.887 & 0.067 & 0.118 \\
\hline $\begin{array}{l}\text { Self-identity } \rightarrow \text { Perceived destination } \\
\text { image } \rightarrow \text { behavioural intention }\end{array}$ & 0.126 & 3.890 & 0.102 & 0.138 \\
\hline $\begin{array}{l}\text { Desire for social interaction } \rightarrow \text { Perceived destination } \\
\text { image } \rightarrow \text { Behavioural intention }\end{array}$ & 0.076 & 2.781 & 0.058 & 0.098 \\
\hline
\end{tabular}

\section{Conclusions and research implications}

This study investigated the relationship between cosmopolitanism, self-identity, and a desire for social interaction on both perceived destination image and behavioural intention. A theoretically derived structural model was developed to explore these relationships. The findings highlight significant relationships between most constructs. Theoretical and managerial implications are presented in following section.

First, the relationships between cosmopolitanism, self-identity, and a desire for social interaction on perceived destination image were tested. Our findings echo studies advocating the importance of these concepts in developing perceptions of what tourists expect to experience at a destination prior to travel (Nelson, 2015; Martin-Santana et al., 2017). Although not fully in-line with the traditional perception of Islamic travel (Aziz, 1995; Burton, 1995), Umrah visitors expect many of the characteristics of a cosmopolitan destination as, despite being held together by the golden thread of the Islamic faith, Mecca attracts visitors from many different countries and nationalities. Expectations pertaining to the cosmopolitan nature of the city will be perceived by a range of prospective tourists. While still bound by the inherent nature of Islam (Aziz, 1995; Burton, 1995), the cosmopolitan image of Mecca is engendered in other ways, through the diverse mix of nationalities and access to local cuisines and attractions (Hughes et al., 2010; MartinsSantana et al., 2017). Second, given the religious nature of Umrah and Mecca, religious self-identity is likely to be strengthened by such travel, supporting previous studies 
suggesting that religion, as a component of self-identity, has an effect on how a tourist perceives a religious destination (Bond et al., 2013; Eid, 2015).

Third, a desire for social interaction has a positive relationship with perceived destination image when considering Umrah, confirming research on religious (Jutla, 2002; Jafari \& Scott, 2014) and non-religious travel (Lee et al., 2004; Yuan et al., 2008), where perceived opportunities to interact with likeminded individuals play an important role in forming destination image. Given the importance of togetherness and unity within Islam (Jafari \& Scott, 2014), the opportunity to interact, communicate, and accompany those who share your religious identity in a place of religious importance may form an appealing image in the mind of prospective travellers.

Cosmopolitanism and a desire for social interaction had a direct positive relationship with behavioural intentions. Visitors who are open-minded about a destination and travel to it voluntarily are likely to extol the destinations' virtues and revisit it if they experience something culturally interesting or unique (Zabkar et al., 2010). In the case of Umrah, with its obvious, inherent cultural associations, the cosmopolitan traveller is perhaps more likely to revisit or recommend travel to Mecca if the standard of accommodation, food, and opportunity to shop for souvenirs is considered high and if supplementary cultural excursions are available (Prayag \& Hosnay, 2014; Henderson, 2011). This is in line with the findings of Martin-Santana et al. (2017) in their study of non-religious travel. Umrah affords tourists the opportunity to meet like-minded people, who share the same faith, in order to undertake structured worship. As group worship is central to the Islamic faith (Jafari \& Scott, 2014), this study builds upon existing understanding of religious travel by suggesting that the social, and not solely religious, elements of Umrah are important in encouraging tourists to recommend voluntary religious travel to others, and this subsequently plays a part in inspiring repeat visit intentions.

Surprisingly, no direct relationship was found between self-identity and behavioural intentions. Although religious identity is clearly a factor in motivating travel to Mecca, and our research found that it is important in generating the perceived image of a destination, tourists do not necessarily consider self-identity noteworthy post-travel. We advance previous studies into the importance of religious travel (Jafari \& Scott, 2014) 
by suggesting that those undertaking Umrah are more inclined to fondly remember other, less religiously-explicit attributes, such as activities undertaken and the people they interacted with, which in turn stimulate recommendations and repeat visits. This may be due to a base expectation of the religiosity of Mecca - it is difficult to recommend a destination to others based on characteristics they are already familiar with. However, while self-identity does not directly influence behavioural intentions, it does when fully mediated by perceived destination image. Tourists are more likely to recommend or revisit a destination if they perceive its image to be consistent with their self-identity. In the context of Umrah, attractions and facilities which offer the opportunity to worship can increase the enjoyment and strengthen religious self-identity, and the fulfilment of this can result in revisit or recommendation intentions.

Finally, as with other studies, perceived destination image has a positive relationship with behavioural intentions (Ekinci et al., 2006; Prayag \& Hosnay, 2014). If the preconceived notion of what to expect when travelling to a destination is actualised, then tourists are more likely to want to return to experience the positive aspects again and to recommend that others do likewise. When considering travel to Mecca, the virtues and importance of Umrah to the Islamic faith have been reiterated over thousands of years, propagating the positive elements of distinct perceived destination image offerings. However, the antecedent concepts of cosmopolitanism and a desire for social interaction suggest that the expectation and reality of the more tangible attributes of a destination must converge in order to stimulate an intention for tourists to revisit or recommend the overall experience (Zabkar et al., 2010). Therefore, even for established destinations of religious importance, it is important to build and develop a robust service offering in order to encourage repeat visits and help to spread positive word of mouth recommendations from returning tourists (Phillips et al., 2013). Ultimately, if a tourist is open to new cultures and eager to interact with others, they are likely to have a much better perception of a destination. If this perception is realised, it will then drive repeat visits and recommendations, as the iconic and gratifying nature of religious destinations supersedes the act of pilgrimage itself.

While managers and marketers craft the image of their destination, this study provides insight into the antecedent factors that help to build its perceived destination image in the eyes of the tourist. It also confirms that this increases the likelihood of 
positive behavioural intentions, such as recommending the destination to others and revisiting in future. The positive effect that social interaction has on a tourist's willingness to recommend or revisit a destination is also important. Destinations should strive to create an environment that offers tourists the opportunity to interact and take part in group activities in order to share their experiences. Religious destinations need not only be about worship and individual reverence, but are more appealing if they stimulate togetherness, unity, and allow the tourist to feel part of a collection of likeminded individuals. This could be as simple as implementing shared eating spaces or the extensive provision of group tours and activities.

Tourists also build an image of a destination based on perceptions of how cosmopolitanism it is. If actualised, tourists are more inclined to share their positive experiences and revisit in the future; destinations should be considered welcoming, diverse, and known for tolerance. If tourists feel welcome and accepted, they are more likely to revisit and recommend the destination to others. Managers can achieve this by offering religious tourist's information in a number of different languages, training frontline staff to be aware of, and how to respond to, the cultural idiosyncrasies of multicultural guests. For religious destinations, managers must be aware that tourists' self-identity is unlikely to have an influence on their intention to revisit or recommend. The religious importance and nature of the destination, although a key motivator for religious travel, should be complemented by other activities and opportunities designed to engender positive behavioural intentions. The religious importance of Umrah often means that the more self-gratifying elements of travel are considered as being of secondary concern (Eid \& El-Gohary, 2015). Instead, those marketing Umrah should use images showing the social and cosmopolitan attributes of Mecca in order to improve tourist perceptions by providing a more nuanced and appealing destination image. Nonetheless, marketers should give the religious elements of Mecca equal footing in order to appeal to the mediating effect of destination image on the religious aspects of self-identity (Eid, 2015). Destination managers should further develop religious travel destinations to encourage 1) tourists to travel for more than the religious element and 2) encourage revisits and recommendations by providing the necessary group activities and environment of tolerance, helping ratify the perceived destination image. 
Despite the originality of this study, some limitations must be acknowledged. First, this study adopts a quantitative methodological approach, with questionnaires employed as the main method of data collection. While every step was taken to ensure that this approach was dependable and valid, a qualitative methodological element could be employed in future to further develop the findings of this study. Future research may opt to undertake qualitative interviews to collect more in-depth data, which will help to explore ethnographic aspects of the behavioural relationships and develop the conceptual model presented. Second, the sample was restricted to Iranian visitors undertaking Umrah. Given the widespread appeal of Umrah, future studies may wish to consider different groups of tourists within the Islamic community. Further, this study focuses on the perceived element of destination image, and is not designed to measure affective or global considerations relating to destination image (Martin-Santana et al., 2017). Future studies could consider the role that these elements of the image formation process have on post-travel behavioural intentions. Finally, this research is another stage in an emerging wider trend of exploring issues related to religious tourism (El-Gohary \& Eid, 2014; Henderson, 2011). Given its focus on one particular aspect of Islamic tourism, in the form of Umrah, an interesting avenue for further research could be to consider the conceptual framework presented in relation to other forms of religious travel.

\section{Appendix 1: descriptive statistics and items}

\begin{tabular}{lccc}
\hline Items & Mean (SD) & Skewness & Kurtosis \\
\hline Self-identity & & & \\
My travelling view says a lot about who I am & $3.46(1.655)$ & 0.862 & -0.210 \\
My travelling view helps me maintain the type of life I & $3.33(1.617)$ & 1.033 & 0.193 \\
strive for & & &
\end{tabular}


When I use travel, others see me the way I want to see me

You can tell a lot about a person when you see or hear his/her traveling view

\section{Cosmopolitanism}

I like to observe people from other cultures, to see what

I can learn from them

I enjoy exchanging ideas with people from other

cultures and countries

I am interested in learning more about people who live

in other countries

I enjoy being with people from other countries to learn about their views and approaches

\section{Desire for social interaction}

I try hard not to do things that will make other people avoid or reject me

I want other people to accept me

I have a strong need to belong

It bothers me a great deal when I am not included in

other people's plans

My feelings are easily hurt when I feel that others do no accept me

\section{Perceived destination image}

Tailor made trips and activities

Exclusive historical and cultural tours

Availability of trained help (e.g., drivers, nanny)

Upscale local transportation facilities (e.g., chauffeurdriven cars)

Language familiarity

Safety and security for you and your family

Local cuisine complies with religious beliefs

Easy to get a tourist visa

Luxury accommodation

Customized services (e.g., travel arrangements)

Friendly people

Destination with a good reputation

High-end shopping areas

Luxury brands for shopping

Gourmet dining

Interesting architecture

Pleasant weather/climate

Rich heritage and history

Well known spa/wellness facilities

\section{Behavioural Intention}

Willingness to recommend

Like to visit again

Intention to visit again

Willingness to return

$\begin{array}{lll}3.62(1.798) & 0.848 & 0.228 \\ 4.14(1.790) & 0.268 & -0.916 \\ & & \\ 4.23(1.757) & 0.094 & 0.697 \\ 3.89(1.831) & 0.263 & 0.757 \\ 4.83(1.901) & 0.243 & 3.211 \\ 4.68(1.756) & 0.191 & 0.882\end{array}$

$\begin{array}{lll}4.13(2.078) & 0.012 & -3.271\end{array}$

$\begin{array}{lll}4.88(1.801) & 0.440 & 0.931\end{array}$

$\begin{array}{lll}5.40(1.728) & 0.744 & 0.544\end{array}$

$\begin{array}{lll}5.17(1.843) & 3.609 & 0.816\end{array}$

$\begin{array}{lll}5.07(1.722) & -3.316 & 1.120\end{array}$

$\begin{array}{lll}5.25(1.716) & -0.346 & 3.335\end{array}$

$\begin{array}{lll}5.14(1.621) & 0.158 & -2.348\end{array}$

$\begin{array}{lll}4.82(1.776) & -0.315 & -0.870\end{array}$

$\begin{array}{lll}4.75(1.695) & -0.491 & -0.769\end{array}$

$\begin{array}{lll}4.74(1.695) & 0.050 & -3.555\end{array}$

$\begin{array}{lll}5.16(1.724) & 0.024 & -0.997\end{array}$

$\begin{array}{lll}4.08(1.966) & 0.573 \quad 2.076\end{array}$

$\begin{array}{lll}4.24(1.879) & 1.390 & 2.001\end{array}$

$\begin{array}{lll}5.59(1.255) & 3.008 & 0.567\end{array}$

$\begin{array}{lll}5.59(1.315) & 0.056 & 2.009\end{array}$

$\begin{array}{lll}5.57(1.323) & 3.099 & 0.786\end{array}$

$\begin{array}{lll}5.55(1.323) & 0.990 & 2.078\end{array}$

$\begin{array}{lll}5.28(1.403) & 0.889 & 2.780\end{array}$

$\begin{array}{lll}5.46(1.259) & 1.078 & 2.086\end{array}$

$2.39(1.648) \quad 4.001 \quad 3.018$

$\begin{array}{lll}2.69(1.824) & 4.239 & 2.785\end{array}$

$\begin{array}{lll}4.07(1.764) & 3.003 & 1.780\end{array}$

$\begin{array}{lll}4.23(1.737) & 2.023 & 3.009\end{array}$

$\begin{array}{lll}3.88(1.799) & 4.098 & 2.157\end{array}$

$\begin{array}{lll}4.80(1.865) & 2.098 & 2.901\end{array}$

$\begin{array}{lll}4.18(1.829) & 0.019 & 0.929\end{array}$

$\begin{array}{lll}3.60(1.798) & 0.097 & -0.895\end{array}$

$\begin{array}{lll}4.74(1.754) & 0.309 & 0.732\end{array}$

$\begin{array}{lll}4.33(1.772) & 0.104 & -0.865\end{array}$ 


\section{References}

Armstrong, J.S., \& Overton, T.S. (1977), Estimating nonresponse bias in mail surveys, Journal of Marketing Research, 14(3), 396-402.

Battour, M., Ismail, M.N., \& Battour, M. (2011). The impact of destination attributes on Muslim tourist's choice, International Journal of Tourism Research, 13(6), 527540.

Berger, J., \& Heath, C. (2007). Where consumers diverge from others: Identity signalling and product domains. Journal of Consumer Research, 34(2), 121-134. 
Bond, N., \& Falk, J. (2013). Tourism and identity-related motivations: why am I here, International Journal of Tourism Research, 15(5), 430-442.

Brady, M. K., Knight, G. A., Cronin, J. J., Tomas, G., Hult, M., \& Keillor, B. D. (2005). Removing the contextual lens: a multinational, multi-setting comparison of service evaluation models, Journal of Retailing, 81(3), 215-230.

Cannon, H. M., \& Yaprak, A. (2002). Will the real-world citizen please stand up! The many faces of cosmopolitan consumer behaviour, Journal of International Marketing, 10(4), 30-52.

Chen, C.F. \& Tsai, D.C. (2007). How destination image and evaluative factors affect behavioural intentions, Tourism Management, 28,1115-1122

Chen, H.J., Chen, P.J., \& Okumus, F. (2013). The relationship between travel constraints and destination image: A case study of Brunei, Tourism Management, 35,198208.

Chin, W.W. (2010). How to write up and report PLS analyses. In V. Esposito Vinzi, W. W. Chin, J. Henseler \& H. Wang (Eds.), Handbook of Partial Least Squares: Concepts, Methods and Applications (pp. 655-690). Berlin: Springer.

Choi, M., Law, R., \& Heo, C.Y. (2016). Shopping destinations and trust-Tourist attitudes: Scale development and validation. Tourism Management, 54,490-501.

Cleveland, M., Laroche, M., \& Hallab, R. (2013). Globalization, culture, religion, and values: Comparing consumption patterns of Lebanese Muslims and Christians, Journal of Business Research, 66,958-967.

Cohen, J.W. (1988). Statistical Power Analysis for the Behavioral Sciences (2nd ed.). Hillsdale, NJ: Lawrence Erlbaum Associates.

Dolnicar, S., \& Grün, B. (2012). Validly measuring destination image in survey studies, Journal of Travel Research, 52(1), 3-14.

Ekinci, Y., \& Hosany, S. (2006). Destination personality: An application of brand personality to tourism destinations, Journal of Travel Research, 45(2),127-139.

Eid, R. (2015). Integrating Muslim customer perceived value, satisfaction, loyalty and retention in the tourism industry: An empirical study, International Journal of Tourism Research, 17(3), 249-260.

Eid, R., \& El-Gohary, H. (2015). The role of Islamic religiosity on the relationship between perceived value and tourist satisfaction, Tourism Management, 46, 477488.

El-Gohary, H., \& Eid, R. (2014). Emerging research on Islamic marketing and tourism in the global economy. Henley, PA.: Business Scientific Reference

Fornell, C., \& Larcker, D.F. (1981). Evaluating structural equation models with unobservable variables and measurement error, Journal of Marketing Research, 18(1), 39-50.

Fowler, F. (2002), Survey research methods (Vol.1), Thousand Oaks, CA: Applied Social Research Method Series.

Granger, K., Lu, V.N., Conduit, J., Veale, R., \& Habel, C. (2014). Keeping the faith! Drivers of participation in spiritually-based communities, Journal of Business Research, 67(2), 68-75.

Hair, J.F.J., Hult, G.T.M., Ringle, C.M., \& Sarstedt, M. (2014). A primer on Partial Least Squares Structural Equation Modeling (PLS-SEM). UK: Sage.

Haq, F., \& Jackson, J. (2009). Spiritual journey to Hajj: Australian and Pakistani experience and expectations, Journal of Management, Spirituality and Religion, 6(2), 141-156. 
Henderson, J.C. (2003). Managing tourism and Islam in peninsular Malaysia, Tourism Management, 24(4), 447-456.

Henderson, J.C. (2011). Religious tourism and its management: The Hajj in Saudi Arabia, International Journal of Tourism Research, 13(6), 541-552.

Henseler, J., Ringle, C.M., \& Sarstedt, M. (2015). A New Criterion for Assessing Discriminant Validity in Variance-based Structural Equation Modeling, Journal of the Academy of Marketing Science, 43(1), 115-135.

Henseler, J., Ringle, C.M., \& Sinkovics, R.R. (2009). The use of partial least squares path modeling in international marketing, Advances in International Marketing, 20,277-319.

Henseler, J., Dijkstra, T. K., Sarstedt, M., Ringle, C. M., Diamantopoulos, A., Straub, D. W., . . Calantone, R. (2014). Common beliefs and reality about PLS comments on Rönkkö and Evermann (2013), Organizational Research Methods, 17(2), 182209.

Horng, J-S., Liu, C-H., Chiu, H-Y., \& Tsai, C-Y. (2012). The role of international tourist perceptions of brand equity and travel intention in culinary tourism, The Service Industries Journal, 32(16), 2607-2621,

Hughes, H., Monterrubio, J.C., \& Miller, A. (2010). 'Gay tourists and host community attitudes, International Journal of Tourism Research, 12(6), 774-786.

Hui, T.K., \& Wan, T.W.D. (2003). Singapore's image as a tourist destination, International Journal of Tourism Research, 5(4), 305-313.

Jafari, J., \& Scott, N. (2014). Muslim world and its tourisms, Annals of Tourism Research, 44,1-19.

Jang, H.C., Lee, B., Park, M., \& Stokowsli, P.A. (2000). Measuring Underlying Meanings of Gambling from the Perspective of Enduring Involvement, Journal of Travel Research, 38(February), 230-238.

Jutla, R.S. (2002). Understanding Sikh pilgrimage, Tourism Recreation Research, 27(2), 65-72.

Kim, S.S., \& Prideaux, B. (2005). Marketing implications arising from a comparative study of international pleasure tourist motivations and other travel-related characteristics of visitors to Korea, Tourism Management, 26(3),347-357.

Kim, S., Im, H. H., \& King, B. E. M. (2015). Muslim travellers in Asia: The destination preferences and brand perceptions of Malaysian tourists, Journal of Vacation Marketing, 21(1), 3-21.

La Finanza Islamica (2017). http://www.lafinanzaislamica.it/wpcontent/uploads/2017/01/SALAAM1201201 7075243.pdf

Lee, C.K., Lee, Y.K., \& Wicks, B.E. (2004). Segmentation of festival motivation by nationality and satisfaction, Tourism Management, 25(1),61-70.

Lee, M.L., \& Back, K-J. (2007). Effects of Destination Image on Meeting Participation Intentions: Empirical Findings from a Professional Association and its Annual Convention, The Service Industries Journal, 27(1), 59-73.

Li, M., \& Cai, L.A. (2012). The effects of personal values on travel motivation and behavioural intention, Journal of Travel Research, 51(4), 473-487.

Lin, Y.H., Lin, F.J. \& Ryan, C. (2014). Tourists' purchase intentions: impact of franchise brand awareness, The Service Industries Journal, 34(9-10), 811-827.

Maitland, R. (2008). Conviviality and everyday life: the appeal of new areas of London for visitors, International Journal of Tourism Research, 10(1), 15-25. 
Mannell, R.C., \& Iso-Ahola, S.E. (1987). Psychological nature of leisure and tourism experience, Annals of Tourism Research, 14(3), 314-331.

Martín-Santana, J.D., Beerli-Palacio, A., \& Nazzareno, P.A. (2017). Antecedents and consequences of destination image gap, Annals of Tourism Research, 62, 13-25.

Martin, M-A, G., Gil-Pechuan, I., \& Soriano, D.R. (2011). Tourism services, The Service Industries Journal, 31(10), 1561-1566

Moutinho, L., Albayrak, T., \& Caber, M. (2012). How Far does Overall Service Quality of a Destination Affect Customers' Post-Purchase Behaviours?, International Journal of Tourism Research, 14(4), 307-322.

Mura, P. (2015). Perceptions of authenticity in a Malaysian homestay-A narrative analysis, Tourism Management, 51,225-233.

Nadeau, J., Heslop, L., O'Reilly, N., \& Luk, P. (2008). Destination in a country image context. Annals of Tourism Research, 35(1), 84-106.

Nazer, A.E. (2012). Sense and sensibility in Islam: Linguistics, context and rationality. United States: Xlibris.

Nelson, V. (2015). Tourist Identities in Narratives of Unexpected Adventure in Madeira, International Journal of Tourism Research, 17(6), 537-544.

Podsakoff, P. M., MacKenzie, S. M., Lee, J., \& Podsakoff, N. P. (2003). Common method variance in behavioral research: a critical review of the literature and recommended remedies, Journal of Applied Psychology, 88(5), 879-903.

Park, D.B., \& Yoon, Y.S. (2009). Segmentation by motivation in rural tourism: A Korean case study. Tourism Management, 30(1), 99-108.

Prayag, G., \& Hosany, S. (2014). When Middle East meets West: Understanding the motives and perceptions of young tourists from United Arab Emirates, Tourism Management, 40, 35-45.

Oktadiana, H., Pearce, P.L., \& Chon, K. (2016). Muslim travellers' needs: What don't we know?, Tourism Management Perspectives, 20, 124-130.

Phillips, J, W, M., Wolfe, K., Hodur, N., \& Leistritz, F. L. (2013). Tourist Word of Mouth and Revisit Intentions to Rural Tourism Destinations: a Case of North Dakota, USA, International Journal of Tourism Research, 15, 93-104.

Qu, Y., \& Qu, H. (2015). Nonutilitarian Tourism Destination Positioning: A Case Study in China, International Journal of Tourism Research, 17(4), 388-398.

Rosenbaum, M.S. (2015). Transformative service research: research that matters, The Service Industries Journal, 35(15-16), 801-805.

Ringle, C. M., Wende, S., \& Becker, J.-M. (2014). SmartPLS 3. from http://www. smartpls.com/.

Sirgy, M.J., \& Su, C. (2000). Destination image, self-congruity, and travel behavior: Toward an integrative model, Journal of Travel Research, 38(4),340-352

Smith, A. (2006). Assessing the contribution of flagship projects to city image change: a quasi-experimental technique, International Journal of Tourism Research, 8(6), 391-404.

Sun, X., Chi, C.G.Q., \& Xu, H. (2013). Developing destination loyalty: The case of Hainan Island, Annals of Tourism Research, 43,547-577.

Stylos, N., Vassiliadis, C., Bellou, V., \& Andronikidis, A. (2016). Destination images, holistic images, and personal normative beliefs: Preictors of intention to revisit a destination, Tourism Management, 53,40-60. 
Walsh, G., Yang, Z., Dose, D., \& Hille, P. (2015). The Effect of Job-Related Demands and Resources on Service Employees' Willingness to Report Complaints: Germany Versus China, Journal of Service Research, 18(2), 193-209.

Weaver, A. (2017). Complementary Contrasts in a Mobile World:'In-Betweenness' and the Selling of Duty-free Products, International Journal of Tourism Research, 19(1), 80-88

Weitlander, D., \& Kohlbacher, M. (2015). Process management practices: organizational (dis-)similarities, The Service Industries Journal, 35(1-2), 44-61.

Wang, H-Y. (2012). Investigating the determinants of travel blogs influencing readers' intention to travel, The Service Industries Journal, 32(2), 231-255.

Wells, V.K., Taheri, B., Gregory-Smith, D., \& Manika, D. (2016). The role of generativity and attitudes on employees home and workplace water and energy saving behaviours, Tourism Management, 56, 63-74.

Williams, A., \& MacKinnon, D.P. (2008). Resampling and distribution of the product methods for testing indirect effects in complex models, Structural Equation Modeling, 15(1), 23-51.

Wu, C. H-J. (2011). A re-examination of the antecedents and impact of customer participation in service, The Service Industries Journal, 31(6), 863-876

Yuan, J.J., Morrison, A.M., Cai, L.A., \& Linton, S. (2008). A model of wine tourist behaviour: a festival approach, International Journal of Tourism Research, 10(3), 207-219.

Zabkar, V., Brencic, M.M., \& Dmitrovic, T. (2010). Modelling perceived quality, visitor satisfaction and behavioural intentions at the destination level. Tourism Management, 31,537-546.

Zamani-Farahani, H., \& Henderson, J.C. (2010). Islamic tourism and managing tourism development in Islamic societies: The cases of Iran and Saudi Arabia, International Journal of Tourism Research, 12(1), 79-89.

Zamani-Farahani, H., \& Eid, R. (2016). Muslim world: A study of tourism \& pilgrimage among OIC Member States, Tourism Management Perspectives, 19, 144-149.

Zhang, H., Fu, X., Cai, L.A., \& Lu, L. (2014). Destination image and tourist loyalty: a meta-analysis, Tourism Management, 40, 213-223. 